\title{
JPEB
}

Jurnal Penelitian Ekonomi dan Bisnis, 3 (1), 2018, Hal : 22 - 38

http://www.jpeb.dinus.ac.id

\section{ANALISIS PENGARUH SOSIALISASI PERPAJAKAN TERHADAP KEPATUHAN WAJIB PAJAK DENGAN KESADARAN SEBAGAI VARIABEL MEDIASI}

\author{
1* 2 \\ G. Tegoeh Boediono , Riana Sitawati , dan Sri Harjanto \\ $1,2,3$ \\ Program Studi Pascasarjana (S2) Akuntansi, Sekolah Tinggi Ilmu Ekonomi (STIE) \\ Dharmaputra Semarang, Semarang, Indonesia \\ *Corresponding Email : tghbdn@ yahoo.com
}

Diterima: Desember 2017; Direvisi: Januari 2018; Dipublikasikan: Maret 2018

\begin{abstract}
The purpose of this study is to analyze the effect of tax socialization on individual taxpayer compliance with individual taxpayer awareness as a mediating variable. The population in this study is an individual taxpayer who has been registered in the Central Semarang Two Primary Tax Office in 2017, with total of 10,661 taxpayers. Calculation of the number of samples using the Slovin formula, the sample used in this study was as many as 100 questionnaires distributed directly in Central Semarang Two Primary Tax Office with the permission of the official in charge of the Tax Office. Data analysis using Partial Least Square (PLS) approach using WarpPLS 4.0 program. Results of the research indicate that the tax socialization variables can affect the awareness of taxpayers by 50,4\% and taxation socialization, and taxpayer awareness can affect taxpayer compliance by 58,5\%. Results show that the tax socialization has a positive effect on individual taxpayer awareness, taxation socialization has a positive effect on individual taxpayer compliance, mandatory awareness tax has a positive effect on individual taxpayer compliance, and the awareness of taxpayers mediates the effect of taxation socialization on individual taxpayer compliance.
\end{abstract}

Keywords : Taxation Socialization; Personal Taxpayer Awareness; Individual Taxpayer Compliance

\section{ABSTRAK}

Tujuan penelitian ini yaitu untuk menganalisis pengaruh sosialisasi perpajakan terhadap kepatuhan wajib pajak orang pribadi dengan kesadaran wajib pajak orang pribadi sebagai variabel mediasi. Populasi pada penelitian ini adalah Wajib Pajak Orang Pribadi yang telah terdaftar di Kantor Pelayanan Pajak Pratama Semarang Tengah Dua yang berjumlah 10.661 wajib pajak. Perhitungan jumlah sampel menggunakan rumus slovin, sampel yang digunakan dalam penelitian ini adalah sebanyak 100 kuesioner yang disebarkan langsung di KPP Pratama Semarang Tengah Dua atas izin pejabat yang berwenang dalam KPP tersebut. Analisis data menggunakan pendekatan Partial Least Square (PLS) dengan menggunakan program WarpPLS 4.0. Hasil penelitian menunjukkan bahwa variabel sosialisasi perpajakan dapat mempengaruhi kesadaran wajib pajak sebesar $50,4 \%$ dan sosialisasi perpajakan, dan kesadaran wajib pajak dapat mempengaruhi kepatuhan wajib pajak sebesar 58,5\%. Hasil penelitian menunjukkan bahwa sosialisasi perpajakan berpengaruh positif terhadap kesadaran wajib pajak orang pribadi, sosialisasi perpajakan berpengaruh positif terhadap kepatuhan wajib pajak orang pribadi, kesadaran wajib pajak berpengaruh positif terhadap kepatuhan wajib pajak orang pribadi, serta kesadaran wajib pajak memediasi pengaruh sosialisasi perpajakan terhadap kepatuhan wajib pajak orang pribadi.

Kata kunci : Sosialisasi Perpajakan; Kesadaran Wajib Pajak Orang Pribadi; Kepatuhan Wajib Pajak Orang Pribadi 


\section{PENDAHULUAN}

Pajak adalah kontribusi wajib kepada negara yang terutang oleh orang pribadi atau badan yang bersifat memaksa berdasarkan Undang - Undang, dengan tidak mendapatkan imbalan secara langsung dan digunakan untuk keperluan negara bagi sebesar-besarnya kemakmuran rakyat (Direktorat Jenderal Pajak, 2013). Sistem perpajakan Indonesia pada saat ini salah satunya menganut sistem self assessment, yakni suatu sistem pemungutan pajak yang memberikan wewenang, kepercayaan, tanggung jawab, kepada Wajib Pajak untuk menghitung, memperhitungkan, membayar, dan melaporkan sendiri besarnya pajak yang terutang dan harus dibayar (Murtopo, 2011).

Fakta di lapangan menunjukkan fenomena dimana sampai saat ini pendapatan Negara dari sektor pajak belum maksimal. Setiap tahun realisasi penerimaan pajak tidak mencapai target. Salah satu indikasi tidak tercapainya target penerimaan pajak, yaitu adanya ketidakpatuhan wajib pajak dalam membayar serta melaporkan Surat Pemberitahuan (SPT). Selain itu, menurut Irawan, Kepala Kanwil I Jawa Tengah, mengatakan bahwa penerimaan pajak pada semester I-2017 ini masih belum tercapai separuh dari target. Dari target penerimaan pajak sebesar Rp 31,6 triliun, sampai bulan Juli 2017 tercapai sekitar 42 persen (Pujangga, 2017). Presentase kepatuhan SPT WP OP kelihatan cenderung menurun dan belum mencapai $100 \%$, hal ini akan berdampak terjadinya penurunan target penerimaan pajak. Kepatuhan pajak merupakan fenomena yang sangat kompleks yang dilihat dari banyak perspektif. Melihat hal tersebut di atas, pemerintah atau dalam hal ini adalah Direktorat Jenderal Pajak terus berupaya untuk meningkatkan penerimaan pajak.

Menurut penelitian Faizin (2016), Wulandari (2015), Sudrajat dan Ompusunggu (2015), serta Puspita (2016) mengungkapkan sosialisasi perpajakan berpengaruh terhadap kepatuhan wajib pajak. Sedangkan, Setyaningrum (2017) dan Winerungan (2013) mengungkapkan sosialisasi perpajakan tidak berpengaruh terhadap kepatuhan wajib pajak. Hasil penelitian terdahulu bervariasi, maka peneliti mengajukkan penelitian ini ditambah dengan variablel kesadaran wajib pajak sebagai mediasi. Kesadaran Wajib Pajak diusulkan menjadi variabel mediasi merujuk hal-hal tersebut: (1) sosialisasi perpajakan berpengaruh terhadap kesadaran wajib pajak (Kurniawan, 2014; Wulandari, 2015; Sudrajat dan Ompusunggu, 2015, serta Puspita, 2016), serta (2) kesadaran wajib pajak berpengaruh terhadap kepatuhan wajib pajak (Manuputy dan Sirait, 2016; Faizin, 2016; Setyaningrum, 2017; Setiyani, 2018; Wulandari, 2015; serta Puspita, 2016).

Kesadaran wajib pajak yaitu kerelaan wajib pajak memberikan kontribusi dana untuk pelaksaan fungsi perpajakan dengan cara membayar pajak tepat waktu dan tepat jumlah (Danarsi, 2017). Menurut Manuputty dan Sirait (2016), diperlukan kesadaran dan kejujuran dari wajib pajak dalam menerapkan sistem perpajakan ini, sebab wajib pajak dituntut untuk mengisi sendiri dan menyampaikan SPT Tahunan dengan benar, lengkap, dan jelas.Semakin tinggi sosialisasi yang intensif maka semakin tinggi kepatuhan wajib pajak, dan semakin tinggi kesadaran wajib pajak maka semakin tinggi juga kepatuhan wajib pajak (Kurniawan, 2014). Disimpulkan bahwa semakin tinggi tingkat kesadaran wajib pajak orang pribadi, maka akan semakin tinggi tingkat sosialisasi perpajakan, sehingga rasa kepatuhan wajib pajak terhadap peraturan perpajakan akan semakin meningkat.

Pada latar belakang masalah terungkap adanya masalah kepatuhan SPT WP OP kelihatan cenderung menurun dan belum mencapai $100 \%$, hal ini akan berdampak terjadinya penurunan target penerimaan pajak. Kepatuhan pajak merupakan fenomena yang sangat kompleks yang dilihat dari banyak perspektif. Melihat hal tersebut di atas, pemerintah atau dalam hal ini adalah Direktorat Jenderal Pajak terus berupaya untuk meningkatkan penerimaan pajak. Di samping itu hasil penelitian pengaruh sosialisasi 
perpajakan terhadap kepatuhan wajib pajak belum konsisten hasilnya. Atas dasar hal tersebut diusulkan mengurangi gap tersebut melalui kesadaran wajib pajak dengan model mediasi. Berdasarkan latar belakang yang telah disampaikan maka dapat dirumuskan beberapa rumusan masalah sebagai berikut apakah: (1) sosialisasi perpajakan berpengaruh terhadap kesadaran wajib pajak, (2) sosialisasi perpajakan berpengaruh terhadap kepatuhan wajib pajak orang pribadi, (3) kesadaran wajib pajak berpengaruh terhadap kepatuhan wajib pajak orang pribadi, (4) kesadaran wajib pajak memediasi pengaruh sosialisasi perpajakan terhadap kepatuhan wajib pajak orang pribadi.

\section{TINJAUAN PUSTAKA}

\section{Theory of Planned Behaviour}

Theory of Planned Behavior (TPB) menjelaskan bahwa perilaku wajib pajak yang tidak patuh (noncompliance) sangat dipengaruhi oleh variable dari sikap, norma subyektif, serta kontrol keperilakuan yang dipersepsikan. Perilaku yang ditimbulkan oleh individu muncul karena adanya niat untuk berperilaku (Tiraada,2013). Theory of planned behavior yang dikemukakan oleh Ajzen menyatakan bahwa persepsi kontrol perilaku berpengaruh secara langsung maupun tidak langsung (melalui niat) terhadap perilaku (Basit, 2014).

Perilaku yang dimunculkan oleh individu timbul karena adanya niat untuk berperilaku. Sedangkan munculnya niat berperilaku ditentukan oleh 3 faktor penentu, yaitu behavioral beliefs, normative beliefs, dan control beliefs. Secara berurutan, behavioral beliefs menghasilkan sikap dan niat terhadap perilaku positif atau negatif, normative beliefs menghasilkan tekanan sosial yang dipersepsikan dan control beliefs menghasilkan kontrol perilaku yang dipersepsikan (Harinurdin, 2009). Kepatuhan menunaikan kewajiban bagi Wajib pajak Orang Pribadi merupakan perilaku individu. Dalam theory of planned behavior (TPB) yang diperkenalkan oleh Ajzen pada tahun 1988, menjelaskan bahwa perilaku seseorang sebagai fungsi dari niat (intention). Niat (intention) seseorang untuk melakukan suatu perilaku dipengaruhi oleh sikapnya terhadap perilaku, norma subyektif dan kontrol perilaku yang dipersepsikan (perceived behavioral control) (Handoyono, 2014).

Theory of Planned Behavior ini relevan untuk menjelaskan perilaku patuh wajib pajak dalam memenuhi kewajibannya membayar pajak dan melaporkan pajak. Adanya niat dari dalam diri wajib pajak dapat ditingkatkan dengan adanya sosialisasi perpajakan untuk menambah kesadaran wajib pajak mengenai peraturan perpajakan. Selain itu, kesadaran wajib pajak juga dapat membuat wajib pajak enggan untuk melanggar peraturan perpajakan, sehingga dapat memaksimalkan kepatuhan wajib pajak dalam memenuhi kewajibannya sebagai wajib pajak.

\section{Kepatuhan Wajib Pajak}

Kepatuhan Wajib Pajak merupakan pemenuhan kewajiban perpajakan yang dilakukan oleh pembayar pajak dalam rangka memberikan kontribusi bagi pembangunan Negara yang diharapkan didalam pemenuhannya dilakukan secara sukarela (Tiraada, 2013).

Ketidakpatuhan pajak adalah ketidakpatuhan dalam memenuhi ketentuan peraturan perpajakan yang berlaku, baik ketidakpatuhan formal maupun ketidakpatuhan material (Hidayat dan Nugroho, 2010). Sesuai dengan penelitian yang dilakukan Hidayat dan Nugroho (2010), instrumen ketidakpatuhan pajak dilihat melalui tiga kepatuhan:pertama, kepatuhan pengisian SPT (filling compliance), yaitu kepatuhan dalam menyerahkan surat pemberitahuan baik tahunan dan masa dengan tepat waktu. Kedua, kepatuhan pembayaran (payment compliance), yaitu kepatuhan dalam melakukan pembayaran pajak terhutang dengan tepat waktu. Ketiga, kepatuhan 
pelaporan (reporting compliance), yaitu kepatuhan dalam melaporkan seluruh pajak yang terhutang. Dua kepatuhan pertama merupakan kepatuhan dalam memenuhi kewajiban perpajakan secara formal, sedangkan kepatuhan yang ketiga merupakan kepatuhan secara material.

\section{Sosialisasi Perpajakan}

Sosialisasi merupakan suatu upaya yang dilakukan Dirjen Pajak melalui berbagai metode untuk memberikan informasi terkait segala peraturan dan kegiatan yang berhubungan dengan perpajakan agar dapat dilaksanakan oleh masyarakat pada umumnya khususnya wajib pajak, baik orang pribadi maupun badan usaha (Faizin, 2016).

Sosialisasi perpajakan yang dilakukan secara intensif, akan dapat meningkatkan pemahaman WP tentang kewajiban membayar pajak sebagai wujud kegotongroyongan nasional dalam menghimpun dana untuk kepentingan pembiayaan pemerintahan dan pembangunan nasional (Kurniawan (2014). Adanya sosialisasi perpajakan akan meningkatkan kesadaran wajib pajak untuk membayar pajak serta mematuhi peraturan perpajakan. Sosialisasi ini masyarakat menjadi mengerti dan paham tentang manfaat membayar pajak serta sanksi jika tidak membayar pajak. Demikian sosialisasi perpajakan ini dapat berpengaruh untuk menambah jumlah wajib pajak dan dapat menimbulkan kepatuhan dari wajib pajak sehingga secara otomatis tingkat kepatuhan wajib pajak akan semakin bertambah juga penerimaan pajak negara akan meningkat (Winerungan, 2013).

\section{Kesadaran Wajib Pajak}

Kesadaran wajib pajak yaitu kerelaan wajib pajak memberikan kontribusi dana untuk pelaksaan fungsi perpajakan dengan cara membayar pajak tepat waktu dan tepat jumlah (Danarsi, 2017). Tingkat kesadaran perpajakan menunjukkan seberapa besar tingkat pemahaman seseorang tentang arti, fungsi dan peranan pajak. Semakin tinggi tingkat pemahaman wajib pajak maka kesadaran pelaksanaan kewajiban perpajakan semakin baik sehingga dapat meningkatkan kepatuhan WP dalam membayar pajak (Faizin, 2016).

\section{Kerangka Pemikiran}

Berdasarkan kajian teori dan penelitian terdahulu maka disusun model atau kerangka pemikiran penelitian seperti gambar sebagai berikut:

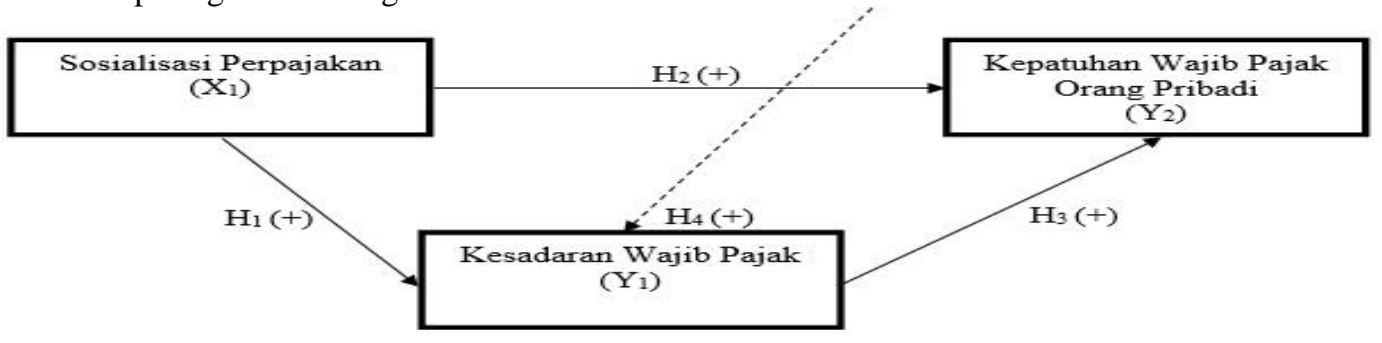

\section{Gambar 1. Kerangka Pemikiran Penelitian}

\section{Sosialisasi Perpajakan Terhadap Kesadaran Wajib Pajak}

Sosialisasi merupakan suatu upaya yang dilakukan Dirjen Pajak melalui berbagai metode untuk memberikan informasi terkait segala peraturan dan kegiatan yang berhubungan dengan perpajakan agar dapat dilaksanakan oleh masyarakat pada umumnya khususnya wajib pajak, baik orang pribadi maupun badan usaha (Faizin, 2016). Kesadaran wajib pajak yaitu kerelaan wajib pajak memberikan kontribusi dana untuk pelaksaan fungsi perpajakan dengan cara membayar pajak tepat waktu dan tepat 
G. Tegoeh Boediono, Riana Sitawati, dan Sri Harjanto : Analisis Pengaruh Sosialisasi Perpajakan Terhadap Kepatuhan Wajib Pajak Dengan Kesadaran Sebagai Variabel Mediasi

jumlah (Danarsi, 2017).

Sosialisasi perpajakan yang dilakukan secara intensif, akan dapat meningkatkan pemahaman WP tentang kewajiban membayar pajak sebagai wujud kegotongroyongan nasional dalam menghimpun dana untuk kepentingan pembiayaan pemerintahan dan pembangunan nasional (Kurniawan (2014). Semakin intensifnya sosialisasi perpajakan akan meningkatkan kesadaran wajib pajak untuk membayar pajak serta mematuhi peraturan perpajakan.

Menurut penelitian Kurniawan (2014), Wulandari (2015), serta Puspita (2016) bahwa sosialisasi perpajakan berpengaruh terhadap kesadaran wajib pajak. Sedangkan, penelitian Setyaningrum (2017) menunjukkan bahwa sosialisasi perpajakan tidak berpengaruh terhadap kesadaran wajib pajak. Berdasarkan pemikiran-pemikiran teoritis Kurniawan (2014), Wulandari (2015), serta Puspita (2016) mengenai pengaruh sosialisasi perpajakan terhadap kesadaran wajib pajak, dapat diturunkan hipotesis penelitian kedua sebagai berikut :

$\mathrm{H}_{1}$ : Sosialisasi perpajakan berpengaruh positif terhadap kesadaran wajib pajak orang pribadi

\section{Sosialisasi Perpajakan Terhadap Kepatuhan Wajib Pajak}

Kepatuhan Wajib Pajak merupakan pemenuhan kewajiban perpajakan yang dilakukan oleh pembayar pajak dalam rangka memberikan kontribusi bagi pembangunan Negara yang diharapkan didalam pemenuhannya dilakukan secara sukarela (Tiraada, 2013). Menggunakan sosialisasi ini masyarakat menjadi mengerti dan paham tentang manfaat membayar pajak serta sanksi jika tidak membayar pajak. Demikian sosialisasi perpajakan ini dapat berpengaruh untuk menambah jumlah wajib pajak dan dapat menimbulkan kepatuhan dari wajib pajak sehingga secara otomatis tingkat kepatuhan wajib pajak akan semakin bertambah juga penerimaan pajak negara akan meningkat (Winerungan, 2013).

Hasil penelitian Faizin (2016), Wulandari (2015), Sudrajat dan Ompusunggu (2015), serta Puspita (2016) mengungkapkan sosialisasi perpajakan berpengaruh terhadap kepatuhan wajib pajak. Sedangkan, Setyaningrum (2017) dan Winerungan (2013) mengungkapkan sosialisasi perpajakan tidak berpengaruh terhadap kepatuhan wajib pajak. Berdasarkan pemikiran-pemikiran teoritis Faizin (2016), Wulandari (2015), Sudrajat dan Ompusunggu (2015), serta Puspita (2016) mengenai pengaruh sosialisasi perpajakan terhadap kepatuhan wajib pajak, dapat diturunkan hipotesis penelitian keempat sebagai berikut :

$\mathrm{H}_{2}$ : Sosialisasi perpajakan berpengaruh positif terhadap kepatuhan wajib pajak orang pribadi

\section{Kesadaran Wajib Pajak Terhadap Kepatuhan Wajib Pajak}

Tingkat kesadaran perpajakan menunjukkan seberapa besar tingkat pemahaman seseorang tentang arti, fungsi dan peranan pajak. Semakin tinggi tingkat pemahaman wajib pajak maka kesadaran pelaksanaan kewajiban perpajakan semakin baik sehingga dapat meningkatkan kepatuhan WP dalam membayar pajak (Faizin, 2016). Hasil penelitian Manuputy dan Sirait (2016), Faizin (2016), Setyaningrum (2017), Setiyani (2018), Wulandari (2015), serta Puspita (2016) menyatakan bahwa kesadaran wajib pajak berpengaruh terhadap kepatuhan wajib pajak. Sedangkan, Danarsi (2017) menemukkan bahwa kesadaran wajib pajak tidak berpengaruh terhadap kepatuhan wajib pajak. Berdasarkan pemikiran-pemikiran teoritis Manuputy dan Sirait (2016), Faizin (2016), Setyaningrum (2017), Setiyani (2018), Wulandari (2015), serta Puspita (2016) mengenai pengaruh kesadaran wajib pajak terhadap kepatuhan wajib pajak, dapat diturunkan hipotesis penelitian kelima sebagai berikut : 
$\mathrm{H}_{3}$ : Kesadaran wajib pajak berpengaruh positif terhadap kepatuhan wajib pajak orang pribadi

\section{Kesadaran Wajib Pajak Memediasi Pengaruh Sosialisasi Perpajakan Terhadap Kepatuhan Wajib Pajak}

Semakin tinggi sosialisasi yang intensif maka semakin tinggi kepatuhan wajib pajak, dan semakin tinggi kesadaran wajib pajak maka semakin tinggi juga kepatuhan wajib pajak (Kurniawan, 2014). Disimpulkan bahwa semakin tinggi tingkat kesadaran wajib pajak orang pribadi, maka akan semakin tinggi tingkat sosialisasi perpajakan, sehingga rasa kepatuhan wajib pajak terhadap peraturan perpajakan akan semakin meningkat. Hasil penelitian Puspita (2018) menunjukkan bahwa Sosialisasi yang dilakukan oleh Dispenda Kota Kediri berpengaruh baik secara langsung maupun melalui variabel perantara kesadaran terhadap kepatuhan wajib pajak Bumi dan Bangunan Kota Kediri. Sedangkan, penelitian Setyaningrum (2017) dan Wulandari (2015) menunjukkan bahwa Kesadaran membayar pajak tidak berpengaruh terhadap hubungan antara Sosialisasi PBB dengan Kepatuhan WP. Berdasarkan pemikiranpemikiran teoritis Puspita (2018) mengenai kesadaran wajib pajak memediasi pengaruh sosialisasi perpajakan terhadap kepatuhan wajib pajak, dapat diturunkan hipotesis penelitian ketujuh sebagai berikut :

$\mathrm{H}_{4}$ : Kesadaran wajib pajak memediasi pengaruh sosialisasi perpajakan terhadap kepatuhan wajib pajak orang pribadi

\section{METODE PENELITIAN}

Populasi pada penelitian ini adalah wajib pajak orang pribadi yang telah terdaftar di Kantor Pelayanan Pajak Pratama Semarang Tengah Dua. Jenis data yang digunakan adalah data primer, yaitu data yang diperoleh dengan menggunakan kuesioner yang disebarkan ke responden yang dituju sebagai sampel penelitian. Menurut Putra (2013), jumlah anggota sampel sering dinyatakan dengan ukuran sampel. Jumlah sampel yang diharapkan $100 \%$ mewakili populasi adalah jumlah anggota populasi itu sendiri. Untuk jumlah populasi yang terlalu banyak akan kita ambil untuk dijadikan sampel dengan harapan jumlah sampel yang kita ambil dapat mewakili populasi yang ada. Perhitungan jumlah sampel menggunakan rumus slovin dengan batas kesalahan $10 \%$ dalam penelitian ini adalah :

$$
n=\frac{N}{1+\mathrm{Ne}^{2}}
$$

Keterangan :

$\mathrm{n} \quad=$ ukuran sampel

$\mathrm{N} \quad=$ jumlah populasi

e $\quad=$ persentase kesalahan yang ditolerir dalam pengambilan sampel $(\mathrm{e}=10 \%)$

Data yang didapat dari hasil penelitian ini adalah data kuantitatif, yang selanjutnya akan dianalisis sesuai dengan jenisnya. Dalam penelitian ini analisis data menggunakan pendekatan Partial Least Square (PLS).PLS adalah salah satu metode penyelesaian Structural Equation Modeling (SEM) yang dalam hal ini lebih tepat dibandingkan dengan teknik-teknik SEM lainnya. PLS path modeling secara umum dibentuk dari dua bagian yaitu model outer dan inner model. Di dalam model persamaan struktural umumnya arah hubungan yang dihipotesiskan antara satu konstruk dengan satu kontruk lainnya mempunyai satu arah kausalitas atau disebut dengan model rekursif (Ghozali dan Latan, 2014). Peneliti menggunakan PLS-SEM dengan menggunakan program WarpPLS 4.0. Diagram jalur dari persamaan struktural yaitu $X_{1}$ dan $\mathrm{X}_{2}$ adalah variabel eksogen dan $\mathrm{Y}_{1}$ serta $\mathrm{Y}_{2}$ adalah variabel endogen. Berikut 
G. Tegoeh Boediono, Riana Sitawati, dan Sri Harjanto : Analisis Pengaruh Sosialisasi Perpajakan Terhadap Kepatuhan Wajib Pajak Dengan Kesadaran Sebagai Variabel Mediasi

tahapan menguji analisis SEM PLS, diantaranya: (1) menguji validitas konvergen, (2) menguji validitas diskriminan, (3) menguji reliabel konstruk, (4) menguji model fit, dan (5) menguji Hipotesis.

Menurut Ghozali (2016), analisis jalur (Path Analysis) merupakan penggunaan analisis jalur untuk menaksir hubungan kausalitas antar variabel yang telah ditentukan sebelumnya berdasarkan teori. Analisis jalur tidak dapat menentukan hubungan sebab akibat dan juga tidak dapat digunakan sebagai substitusi bagi peneliti untuk melihat hubungan kausalitas antar variabel. Model persamaan dalam analisis jalur yang digunakan dalam penelitian ini adalah analisis jalur sebagai berikut :

a. $Y_{1}=\beta_{1} X_{1}+e_{1} \quad$ (Jalur I)

b. $Y_{2}=\beta_{3} Y_{1}+\beta_{2} X_{1}+e_{2}$ (Jalur II)

Dimana :

$\mathrm{Y}_{1} \quad$ : Kesadaran Wajib Pajak

$\mathrm{Y}_{2} \quad$ : Kepatuhan Wajib Pajak

$\mathrm{X}_{1} \quad$ : Sosialisasi Perpajakan

$\beta \quad$ : Koefisiensi Jalur

e : Error/residu

Besarnya pengaruh masing-masing variabel bebas (exogeneous) terhadap variabel terikat (endegeneous) dapat dijelaskan berdasarkan model diagram jalur sebagai berikut

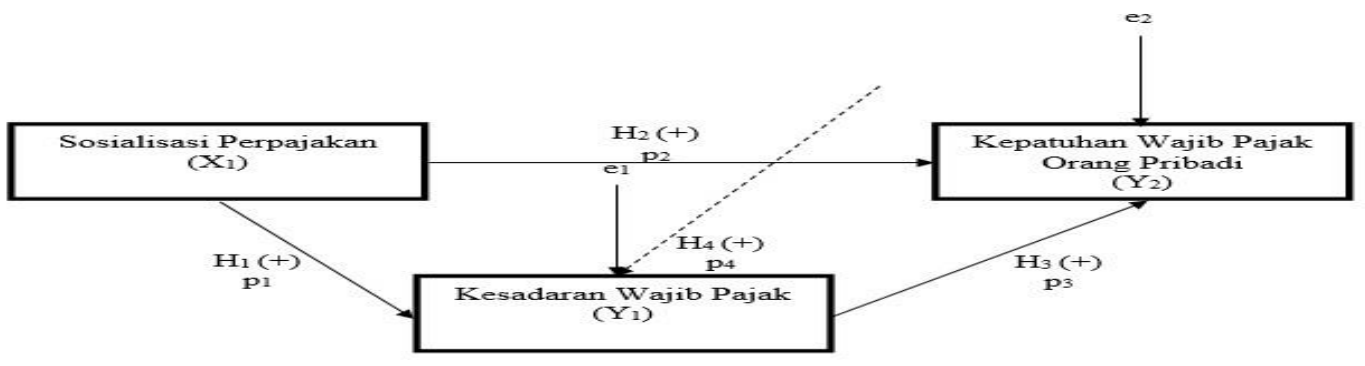

Gambar 2. Model Diagram Jalur

\section{HASIL DAN PEMBAHASAN}

Perhitungan jumlah sampel menggunakan rumus slovin dengan batas kesalahan $10 \%$ dalam penelitian ini adalah :

$$
\begin{aligned}
& n=\frac{N}{1+\mathrm{Ne}^{2}} \\
& n=\frac{10.661}{1+\left(10.661 \times(0.1)^{2}\right)} \\
& n=\frac{10.661}{107,61} \\
& n=99,071 \text { responden }
\end{aligned}
$$

Keterangan :

(dibulatkan menjadi 100 responden)

$\mathrm{n} \quad=$ ukuran sampel

$\mathrm{N} \quad=$ jumlah populasi

$\mathrm{e} \quad=$ persentase kesalahan yang ditolerir dalam pengambilan sampel $(\mathrm{e}=10 \%)$

Berdasarkan pertimbangan di atas, sampel yang digunakan dalam penelitian ini adalah sebanyak 100 kuesioner yang disebarkan langsung di Tempat Pelayanan Terpadu KPP Pratama Semarang Tengah Dua atas izin pejabat yang berwenang dalam KPP 
tersebut. Dengan menggunakan 100 kuesioner diharapkan hasil penelitian ini akan menghasilkan output yang akurat dan valid.

Evaluasi model pengukuran atau outer model dilakukan untuk menilai reliabilitas dan validitas dari indikator-indikator pembentuk konstruk laten (Ghozali dan Latan, 2014). Construct validity atau factorial validity digunakan untuk mengukur konsep dari konstruk laten. Pengujian validitas dimaksudkan untuk menguji apakah item/indicator yang merepresentasi konstruk laten valid ataukah tidak untuk menjelaskan konstruk laten untuk diukur. Construct validity terbagi menjadi dua yaitu :konvergen dan diskriminan (Ghozali dan Latan, 2014).

\section{Validitas Konvergen}

Validitas konvergen bertujuan untuk menguji korelasi antar item/indicator untuk mengukur konstruk. Dengan kata lain validitas konvergen ingin mengkonfirmasi pengukuran konstruk (Ghozali dan Latan, 2014). Rule of thumb yang biasanya digunakan untuk menilai factor loading yaitu harus lebih besar dari 0.7 untuk penelitian yang bersifat confirmatory dan nilai loading faktor antara 0.6 - 0.7 masih dapat diterima untuk penelitian yang bersifat exploratory (Ghozali dan Latan, 2014). Selain itu direkomendasikan nilai $P$-value harus $<0,05$.

Tabel 1. Validitas Konvergen

\begin{tabular}{|c|c|c|c|c|c|c|}
\hline & Y1 & Y2 & X1 & Type (as defined) & SE & $P$ value \\
\hline Y11 & $(0.689)$ & -0.076 & -0.376 & Reflective & 0.076 & $<0.001$ \\
\hline Y12 & $(0.775)$ & 0.126 & -0.309 & Reflective & 0.076 & $<0.001$ \\
\hline Y13 & $(0.796)$ & -0.318 & 0.241 & Reflective & 0.076 & $<0.001$ \\
\hline Y14 & $(0.791)$ & -0.207 & -0.031 & Reflective & 0.076 & $<0.001$ \\
\hline Y15 & $(0.714)$ & 0.183 & 0.065 & Reflective & 0.076 & $<0.001$ \\
\hline Y16 & $(0.678)$ & 0.355 & 0.419 & Reflective & 0.076 & $<0.001$ \\
\hline Y21 & 0.040 & $(0.742)$ & 0.091 & Reflective & 0.076 & $<0.001$ \\
\hline Y22 & 0.039 & $(0.867)$ & -0.021 & Reflective & 0.076 & $<0.001$ \\
\hline Y23 & 0.048 & $(0.825)$ & -0.241 & Reflective & 0.076 & $<0.001$ \\
\hline Y24 & 0.007 & $(\mathbf{0 . 7 8 8})$ & 0.135 & Reflective & 0.076 & $<0.001$ \\
\hline Y25 & -0.170 & $(0.818)$ & 0.302 & Reflective & 0.076 & $<0.001$ \\
\hline Y26 & 0.048 & $(0.747)$ & 0.003 & Reflective & 0.076 & $<0.001$ \\
\hline Y27 & -0.006 & $(\mathbf{0 . 8 7 3 )}$ & -0.236 & Reflective & 0.076 & $<0.001$ \\
\hline X11 & -0.177 & -0.097 & $(0.876)$ & Reflective & 0.076 & $<0.001$ \\
\hline X12 & -0.112 & -0.078 & $(0.885)$ & Reflective & 0.076 & $<0.001$ \\
\hline X13 & -0.042 & 0.000 & $(0.875)$ & Reflective & 0.076 & $<0.001$ \\
\hline X14 & -0.031 & -0.033 & $(0.886)$ & Reflective & 0.076 & $<0.001$ \\
\hline X15 & 0.037 & -0.082 & $(0.888)$ & Reflective & 0.076 & $<0.001$ \\
\hline X16 & -0.046 & -0.033 & $(0.932)$ & Reflective & 0.076 & $<0.001$ \\
\hline X17 & 0.096 & -0.038 & $(0.929)$ & Reflective & 0.076 & $<0.001$ \\
\hline X18 & -0.036 & 0.103 & $(0.921)$ & Reflective & 0.076 & $<0.001$ \\
\hline X19 & 0.003 & 0.073 & $(0.921)$ & Reflective & 0.076 & $<0.001$ \\
\hline X110 & -0.017 & 0.042 & (0.933) & Reflective & 0.076 & $<0.001$ \\
\hline X111 & 0.061 & 0.084 & $(\mathbf{0 . 8 8 9})$ & Reflective & 0.076 & $<0.001$ \\
\hline
\end{tabular}


G. Tegoeh Boediono, Riana Sitawati, dan Sri Harjanto : Analisis Pengaruh Sosialisasi Perpajakan Terhadap Kepatuhan Wajib Pajak Dengan Kesadaran Sebagai Variabel Mediasi

\begin{tabular}{ccccccc}
\hline & Y1 & Y2 & X1 & Type (as defined) & SE & P value \\
\hline X112 & -0.024 & 0.064 & $\mathbf{( 0 . 9 0 6 )}$ & Reflective & 0.076 & $<\mathbf{0 . 0 0 1}$ \\
$\mathbf{X 1 1 3}$ & 0.072 & 0.050 & $\mathbf{( 0 . 9 3 5 )}$ & Reflective & 0.076 & $<\mathbf{0 . 0 0 1}$ \\
X114 & 0.129 & -0.057 & $\mathbf{( 0 . 9 2 6 )}$ & Reflective & 0.076 & $<\mathbf{0 . 0 0 1}$ \\
$\mathbf{X 1 1 5}$ & -0.019 & 0.052 & $\mathbf{( 0 . 9 3 3 )}$ & Reflective & 0.076 & $<\mathbf{0 . 0 0 1}$ \\
$\mathbf{X 1 1 6}$ & 0.092 & -0.058 & $\mathbf{( 0 . 9 2 8 )}$ & Reflective & 0.076 & $<\mathbf{0 . 0 0 1}$ \\
\hline
\end{tabular}

Berdasarkan hasil output olah data pada tabel 1 menyatakan bahwa nilai factor loading > 0,6 untuk semua indikator yang mengukur besarnya variabel kesadaran wajib pajak, kepatuhan wajib pajak, dan sosialisasi perpajakan, maka dapat disimpulkan untuk semua butir jawaban tersebut sudah valid dan dapat digunakan untuk penelitian.

\section{Validitas Diskriminan}

Validitas diskriminan bertujuan untuk menguji item/indikator dari dua konstruk yang seharusnya tidak berkorelasi tinggi (Ghozali dan Latan, 2014). Kriteria yang digunakan adalah: Akar kuadrat Average Variance Extracted (AVE) > korelasi antar konstruk laten (Ghozali dan Latan, 2014).

Tabel 2. Validitas Diskriminan

\begin{tabular}{cccc}
\hline & Y1 & Y2 & X1 \\
\hline Y1 & $\mathbf{( 0 . 7 4 2 )}$ & 0.710 & 0.687 \\
Y2 & 0.710 & $\mathbf{( 0 . 8 1 0 )}$ & 0.623 \\
X1 & 0.687 & 0.623 & $\mathbf{( 0 . 9 1 1 )}$ \\
\hline
\end{tabular}

Berdasarkan tabel 2 di atas, diketahui bahwa nilai Akar kuadrat Average Variance Extracted (AVE) variabel moral kesadaran wajib pajak sebesar 0,742 > korelasi antar konstruk laten, nilai akar kuadrat AVE variabel kepatuhan wajib pajak sebesar 0,810 > korelasi antar konstruk laten, dan nilai akar kuadrat AVE variabel sosialisasi perpajakan sebesar 0,911 > korelasi antar konstruk laten. Maka dapat disimpulkan untuk semua indikator tersebut sudah valid dan dapat digunakan untuk penelitian.

\section{Reliabilitas}

Uji reliabilitas dilakukan untuk membuktikan akurasi, konsistensi dan ketepatan item/indicator dalam mengukur konstruk. Dalam PLS-SEM dengan menggunakan program WarpPLS 4.0, untuk mengukur reliabilitas suatu konstruk dengan indikator refleksif dapat dilakukan dengan melihat nilai Composite Reliability dan Cronbach Alpha. Nilai Composite Reliability > 0,7 dan Cronbach Alpha > 0,7 (Ghozali dan Latan, 2014).

Tabel 3. Reliabilitas

\begin{tabular}{cccc}
\hline & Y1 & Y2 & X1 \\
\hline R-Squared & 0.509 & 0.593 & \\
Adj. R-Squared & 0.504 & 0.585 & \\
Composite reliab. & $\mathbf{0 . 8 8 0}$ & $\mathbf{0 . 9 3 0}$ & $\mathbf{0 . 9 8 7}$ \\
Cronbach's alpha & $\mathbf{0 . 8 3 6}$ & $\mathbf{0 . 9 1 2}$ & $\mathbf{0 . 9 8 6}$ \\
Avg. Var. Extrac. & 0.551 & 0.656 & 0.829 \\
Full Collin. VIF & 2.512 & 2.170 & 2.036 \\
Q-squared & 0.507 & 0.604 & \\
\hline
\end{tabular}


Berdasarkan hasil output olah data 3 di atas, diketahui bahwa Nilai Composite Reliability variabel kesadaran wajib pajak sebesar $0,880>0,7$, kepatuhan wajib pajak sebesar 0,930 >0,7, dan sosialisasi perpajakan sebesar 0,987 $>0,7$. Serta Nilai Cronbach Alpha variabel kesadaran wajib pajak sebesar 0,836 >0,7, kepatuhan wajib pajak sebesar 0,912 >0,7, dan sosialisasi perpajakan sebesar 0,986 >0,7. Maka dapat disimpulkan untuk semua indikator tersebut sudah reliabel dan dapat digunakan untuk penelitian.

\section{Model Fit}

Inner model menunjukkan hubungan atau kekuatan estimasi antar variabel laten atau konstruk berdasarkan pada substantive theory (Ghozali dan Latan, 2014). Program WarpPLS 4.0 mempunyai 4 (empat) ukuran fit model antara lain average path coefficient (APC), average $R$-squared (ARS), average adjusted $R$-squared (AARS), dan average full collinearity VIF (AFVIF).

Program WarpPLS 4.0 mempunyai 4 (empat) ukuran fit model antara lain average path coefficient (APC), average $R$-squared (ARS), average adjusted $R$-squared (AARS), dan average full collinearity VIF (AFVIF) (Sholihin dan Ratmono, 2013). Nilai cut-off $P$-value untuk APC, ARS dan AARS yang direkomendasikan sebagai model fit adalah $\leq 0,05$ dengan level signifikansi yang digunakan adalah 5\% (Ghozali dan Latan, 2014).

Idealnya, nilai AFVIF yang direkomendasikan untuk kedua ukuran tersebut harus $\leq 3,3$ dengan asumsi kebanyakan konstruk/variabel di dalam model diukur dengan dua atau lebih indikator (Ghozali dan Latan, 2014).

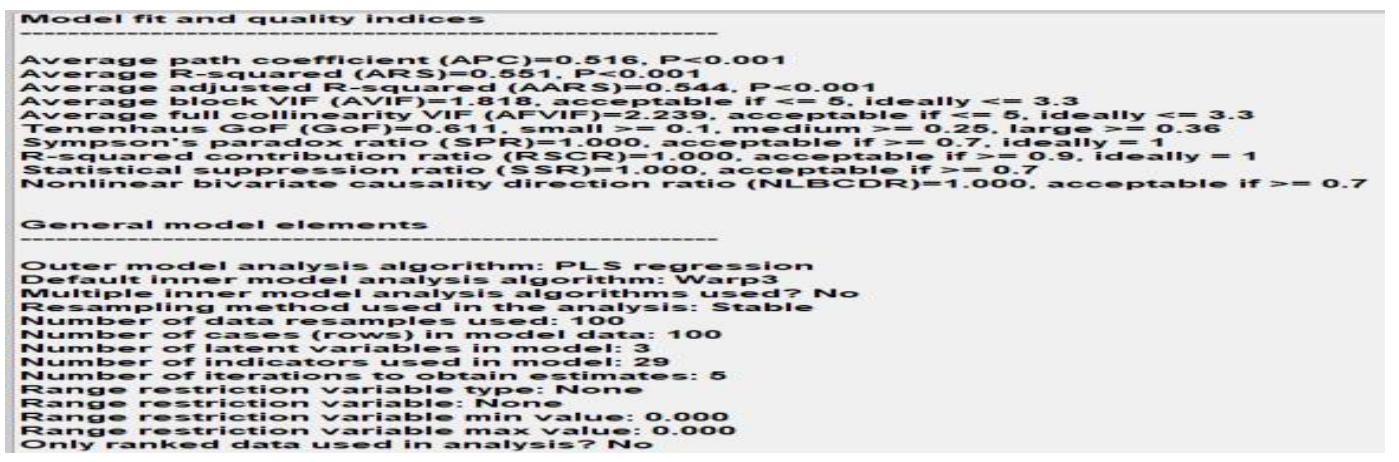

\section{Gambar 3. Model Fit}

Berdasarkan gambar 3 di atas, nilai $P$-value untuk APC sebesar $\mathrm{P}<0,001$ lebih kecil dari 0,05, ARS sebesar $\mathrm{P}<0,001$ lebih kecil dari 0,05 dan AARS sebesar $\mathrm{P}<0,001$ lebih kecil dari 0,05, maka model penelitian ini fit untuk dapat mengukur kualitas model. Nilai AFVIF sebesar 2,239 < 3,3, maka AFVIF memenuhi kriteria ideal fit model.

\section{Menguji Hipotesis}

Berdasarkan tujuan-tujuan penelitian, maka rancangan uji hipotesis yang dapat dibuat merupakan rancangan uji hipotesis dalam penelitian ini disajikan berdasarkan tujuan penelitian. Tingkat kepercayaan yang digunakan adalah 95\%, sehingga tingkat presisi atau batas ketidakakuratan sebesar $(\alpha)=5 \%=0,05$. Besarnya pengaruh masingmasing variabel independen terhadap variabel dependen dan untuk menguji $\mathrm{H}_{1}, \mathrm{H}_{2}$, dan $\mathrm{H}_{3}$ dapat dijelaskan berdasarkan model diagram jalur sebagai berikut : 
G. Tegoeh Boediono, Riana Sitawati, dan Sri Harjanto : Analisis Pengaruh Sosialisasi Perpajakan Terhadap Kepatuhan Wajib Pajak Dengan Kesadaran Sebagai Variabel Mediasi

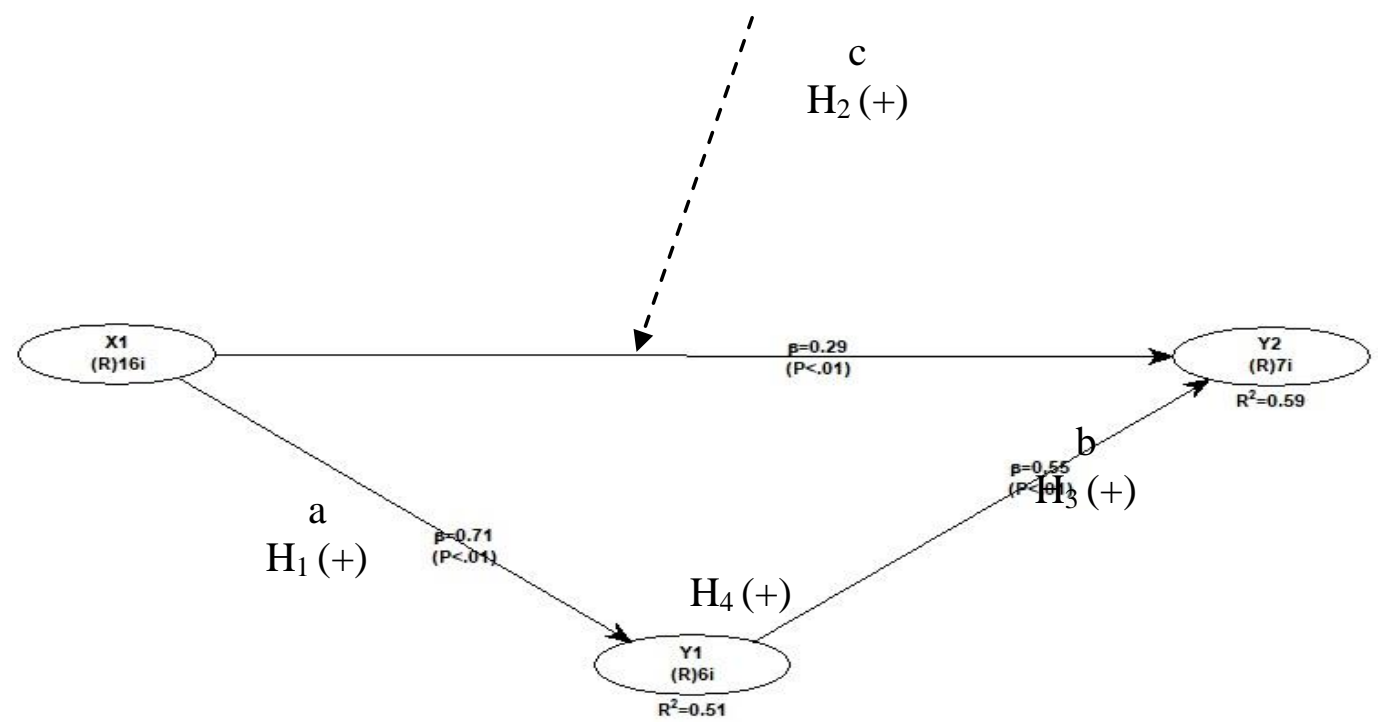

Gambar 4. Model Diagram Jalur

Tabel 4. Path Coefficients $\mathrm{H}_{1}, \mathrm{H}_{2}$, dan $\mathrm{H}_{3}$

\begin{tabular}{cccc}
\hline & Y1 & Y2 & X1 \\
\hline Y1 & & & 0.713 \\
Y2 & 0.548 & & 0.286 \\
X1 & & & \\
\hline
\end{tabular}

Tabel 5. $P$ Values $\mathrm{H}_{1}, \mathrm{H}_{2}$, dan $\mathrm{H}_{3}$

\begin{tabular}{cccc}
\hline & Y1 & Y2 & X1 \\
\hline Y1 & & & $<0.001$ \\
Y2 & $<0.001$ & & $<0.001$ \\
$\mathbf{X 1}$ & & & \\
\hline
\end{tabular}

Nilai signifikansi variabel sosialisasi perpajakan sebesar $<0,001$ lebih kecil dari 0,05, maka variabel sosialisasi perpajakan berpengaruh terhadap kesadaran wajib pajak orang pribadi. Berdasarkan tabel 4 di atas, analisis pengaruh sosialisasi perpajakan terhadap variabel kesadaran wajib pajak orang pribadi menunjukkan bahwa variabel sosialisasi perpajakan memiliki hubungan positif terhadap variabel kesadaran wajib pajak orang pribadi yang ditunjukkan oleh $\beta_{1}$ yang bernilai positif sebesar 0,713 . Berdasarkan hasil tersebut $\mathrm{H}_{1}$ diterima yaitu sosialisasi perpajakan berpengaruh positif terhadap kesadaran wajib pajak orang pribadi. Disimpulkan bahwa semakin intensifnya sosialisasi perpajakan akan meningkatkan kesadaran wajib pajak untuk membayar pajak serta mematuhi peraturan perpajakan.

Nilai $p$ value variabel sosialisasi terhadap kepatuhan WP OP sebesar $<0,001$ lebih kecil dari 0,05, maka variabel sosialisasi perpajakan berpengaruh terhadap kepatuhan wajib pajak. Berdasarkan tabel 4 kolom path coefficients, analisis pengaruh variabel sosialisasi perpajakan terhadap variabel kepatuhan wajib pajak menunjukkan bahwa variabel sosialisasi perpajakan memiliki hubungan positif terhadap variabel kepatuhan wajib pajak yang ditunjukkan oleh $\beta_{2}$ yang bernilai positif sebesar 0,286. Berdasarkan hasil tersebut $\mathrm{H}_{2}$ diterima yaitu sosialisasi perpajakan berpengaruh positif terhadap kepatuhan wajib pajak orang pribadi. Disimpulakan bahwa menggunakan sosialisasi ini 
masyarakat menjadi mengerti dan paham tentang manfaat membayar pajak serta sanksi jika tidak membayar pajak. Demikian sosialisasi perpajakan ini dapat berpengaruh untuk menambah jumlah wajib pajak dan dapat menimbulkan kepatuhan dari wajib pajak sehingga secara otomatis tingkat kepatuhan wajib pajak akan semakin bertambah juga penerimaan pajak negara akan meningkat (Winerungan, 2013).

Nilai signifikansi variabel kesadaran terhadap kepatuhan wajib pajak sebesar $<0,001$ lebih kecil dari 0,05, maka variabel kesadaran WP OP berpengaruh terhadap kepatuhan wajib pajak. Berdasarkan tabel 4 tersebut, hasil analisis pengaruh variabel kesadaran wajib pajak terhadap variabel kepatuhan wajib pajak menunjukkan bahwa variabel kesadaran wajib pajak memiliki hubungan positif terhadap variabel kepatuhan wajib pajak yang ditunjukkan oleh $\beta_{3}$ yang bernilai positif sebesar 0,548. Berdasarkan hasil tersebut $\mathrm{H}_{3}$ diterima yaitu kesadaran wajib pajak berpengaruh positif terhadap kepatuhan wajib pajak orang pribadi. Disimpulkan bahwa tingkat kesadaran perpajakan menunjukkan seberapa besar tingkat pemahaman seseorang tentang arti, fungsi dan peranan pajak. Semakin tinggi tingkat pemahaman wajib pajak maka kesadaran pelaksanaan kewajiban perpajakan semakin baik sehingga dapat meningkatkan kepatuhan WP dalam membayar pajak (Faizin, 2016).

\section{Tabel 6. Efek Mediasi (Indirect and Total Effects)}

\begin{tabular}{ccccc}
\hline P values of indirect effects for paths with 2 segments & & & \\
\hline & & & & \\
Y1 & Y1 & Y2 & X1 \\
Y2 & & & \\
X1 & & & $<0.001$ \\
\hline
\end{tabular}

Kolom $P$ values of indirect effects for paths with 2 segments pada tabel 6 di atas menunjukkan nilai signifikansi sosialisasi perpajakan sebesar $<0,001$ lebih kecil dari 0,05, maka kesadaran wajib pajak memediasi pengaruh sosialisasi perpajakan terhadap kepatuhan wajib pajak. Selanjutnya untuk mengetahui besarnya variance indirect effect penulis dapat menghitungnya dengan menggunakan rumus Variance Accounted For (VAF). Menurut Ghozali dan Latan (2014), VAF dapat dihitung dengan menggunakan rumus dibawah ini :

$\mathrm{a}=\beta_{1}=0,713$

$\mathrm{b}=\beta_{3}=0,548$

$\mathrm{c}=\beta_{2}=0,286$

$$
\begin{aligned}
V A F & =\frac{\mathrm{ax} \mathrm{b}}{(\mathrm{axb})+\mathrm{c}} \times 100 \% \\
& =\frac{0,713 \times 0,548}{(0,713 \times 0,548)+0,286} \times 100 \% \\
& =\frac{0,390724}{0,676724} \times 100 \% \\
& =57,74 \%
\end{aligned}
$$

Berdasarkan perhitungan di atas, menujukkan variance indirect effect kesadaran wajib pajak memediasi pengaruh sosialisasi perpajakan terhadap kepatuhan wajib pajak sebesar 57,74\%. Hasil analisis yang dilakukan memberikan dukungan terhadap 
hipotesis keempat yang diajukan yaitu kesadaran wajib pajak memediasi pengaruh sosialisasi perpajakan terhadap kepatuhan wajib pajak orang pribadi $\left(\mathrm{H}_{4}\right.$ diterima). Disimpulkan bahwa semakin tinggi sosialisasi yang intensif maka semakin tinggi kepatuhan wajib pajak, dan semakin tinggi kesadaran wajib pajak maka semakin tinggi juga kepatuhan wajib pajak (Kurniawan, 2014). Disimpulkan bahwa semakin tinggi tingkat kesadaran wajib pajak orang pribadi, maka akan semakin tinggi tingkat sosialisasi perpajakan, sehingga rasa kepatuhan wajib pajak terhadap peraturan perpajakan akan semakin meningkat.

\section{Pembahasan}

Hasil uji hipotesis pertama, menunjukkan bahwa sosialisasi perpajakan berpengaruh positif terhadap kesadaran wajib pajak orang pribadi $\left(\mathrm{H}_{1}\right.$ diterima). Sosialisasi perpajakan yang dilakukan secara intensif, akan dapat meningkatkan pemahaman WP tentang kewajiban membayar pajak sebagai wujud kegotongroyongan nasional dalam menghimpun dana untuk kepentingan pembiayaan pemerintahan dan pembangunan nasional (Kurniawan, 2014). Semakin intensifnya sosialisasi perpajakan akan meningkatkan kesadaran wajib pajak untuk membayar pajak serta mematuhi peraturan perpajakan.

Penelitian yang dilakukan oleh penulis dengan sampel 100 wajib pajak orang pribadi di KPP Pratama Semarang Tengah Dua menemukan bahwa sosialisasi perpajakan berpengaruh positif terhadap kesadaran wajib pajak, sejalan dengan penelitian yang dilakukan oleh peneliti Kurniawan (2014) dengan sampel 100 WP OP yang telah disensus pajak yang terdaftar di KPP Pratama Banyuwangi, Wulandari (2015) dengan sampel 100 wajib pajak orang Pribadi yang melakukan pekerjaan bebas dan mempunyai kegiatan usaha di KPP Pratama Pekanbaru Senapelan, serta Puspita (2016) dengan sampel 100 wajib pajak bumi dan bangunan yang berada di bawah pengawasan Dispenda Kota Kediri tahun 2015.

Hasil uji hipotesis kedua, menunjukkan bahwa sosialisasi perpajakan berpengaruh positif terhadap kepatuhan wajib pajak orang pribadi $\left(\mathrm{H}_{2}\right.$ diterima). Menggunakan sosialisasi ini masyarakat menjadi mengerti dan paham tentang manfaat membayar pajak serta sanksi jika tidak membayar pajak. Demikian sosialisasi perpajakan ini dapat berpengaruh untuk menambah jumlah wajib pajak dan dapat menimbulkan kepatuhan dari wajib pajak sehingga secara otomatis tingkat kepatuhan wajib pajak akan semakin bertambah juga penerimaan pajak negara akan meningkat (Winerungan, 2013). Semakin meningkatnya sosialisasi perpajakan yang dilakukan oleh pemerintah maka akan meningkatkan rasa kepatuhan wajib pajak orang pribadi untuk membayar tepat waktu dan melaporkan dengan benar.

Hasil penelitian Faizin (2016) dengan sampel 102 KK di RT 4 Desa Mojoranu Kecamatan Dander Kabupaten Bojonegoro, Wulandari (2015) dengan sampel 100 wajib pajak orang Pribadi yang melakukan pekerjaan bebas dan mempunyai kegiatan usaha di KPP Pratama Pekanbaru Senapelan, Sudrajat dan Ompusunggu (2015) dengan 400 sampel Wajib Pajak orang pribadi (WP OP) yang ada di Kanwil DJP Jakarta Selatan, serta Puspita (2016) dengan 100 wajib pajak bumi dan bangunan yang berada di bawah pengawasan Dispenda Kota Kediri tahun 2015 sejalan dengan penelitian yang dilakukan oleh penulis dengan sampel 100 wajib pajak orang pribadi di KPP Pratama Semarang Tengah Dua, yaitu sosialisasi perpajakan berpengaruh positif terhadap kepatuhan wajib pajak.

Hasil uji hipotesis ketiga, menyatakan bahwa kesadaran wajib pajak berpengaruh positif terhadap kepatuhan wajib pajak orang pribadi $\left(\mathrm{H}_{3}\right.$ diterima). Tingkat kesadaran perpajakan menunjukkan seberapa besar tingkat pemahaman seseorang tentang arti, fungsi dan peranan pajak. Semakin tinggi tingkat pemahaman wajib pajak maka 
kesadaran pelaksanaan kewajiban perpajakan semakin baik sehingga dapat meningkatkan kepatuhan WP dalam membayar pajak (Faizin, 2016). Semakin tinggi tingkat kesadaran yang dimiliki oleh wajib pajak, maka wajib pajak tersebut akan semakin patuh untuk menjalankan laporan pajak dengan benar, tepat waktu dan jujur.

Hasil penelitian Manuputy dan Sirait (2016) dengan sampel 100 responden di KPP Pratama Jakarta Penjaringan di daerah Jakarta Barat, Faizin (2016) dengan sampel 102 KK di RT 4 Desa Mojoranu Kecamatan Dander Kabupaten Bojonegoro, Setyaningrum (2017) dengan sampel 100 Wajib Pajak Orang Pribadi di Kantor Badan Keuangan Daerah Kota Pekalongan, Setiyani (2018) dengan sampel 150 wajib pajak orang pribadi yang ada di kota Semarang dan memiliki Nomor Pokok Wajib Pajak (NPWP) yang terdaftar pada Kantor Pelayanan Pajak di wilayah kota Semarang, Wulandari (2015) dengan sampel 100 wajib pajak orang Pribadi yang melakukan pekerjaan bebas dan mempunyai kegiatan usaha di KPP Pratama Pekanbaru Senapelan, serta Puspita (2016) dengan sampel 100 wajib pajak bumi dan bangunan yang berada di bawah pengawasan Dispenda Kota Kediri tahun 2015, sesuai dengan hasil penelitian yang dilakukan oleh penulis dengan sampel 100 wahib pajak di KPP Pratama Semarang Tengah Dua yaitu kesadaran wajib pajak berpengaruh positif terhadap kepatuhan wajib pajak.

Hasil uji hipotesis keempat kesadaran wajib pajak memediasi pengaruh sosialisasi perpajakan terhadap kepatuhan wajib pajak orang pribadi $\left(\mathrm{H}_{4}\right.$ diterima). Semakin tinggi sosialisasi yang intensif maka semakin tinggi kepatuhan wajib pajak, dan semakin tinggi kesadaran wajib pajak maka semakin tinggi juga kepatuhan wajib pajak (Kurniawan, 2014). Disimpulkan bahwa semakin tinggi tingkat kesadaran wajib pajak orang pribadi, maka akan semakin tinggi tingkat sosialisasi perpajakan, sehingga rasa kepatuhan wajib pajak terhadap peraturan perpajakan akan semakin meningkat. Hasil penelitian Puspita (2018) pada Dispenda Kota Kediri tahun 2015 sejalan dengan penelitian yang dilakukan oleh penulis di KPP Pratama Semarang Tengah Dua yang menunjukkan bahwa Sosialisasi berpengaruh baik secara langsung maupun melalui variabel perantara kesadaran terhadap kepatuhan wajib pajak Bumi dan Bangunan Kota Kediri.

\section{SIMPULAN}

Berdasarkan pada hasil analisis penelitian dan pembahasan pada bagian BAB IV, maka dapat diambil kesimpulan, diantaranya adalah sebagai berikut: Nilai signifikansi variabel sosialisasi perpajakan sebesar $<0,001$ lebih kecil dari 0,05 dan $\beta_{1}$ yang bernilai positif sebesar 0,713 . Berdasarkan hasil tersebut $\mathrm{H}_{1}$ diterima yaitu sosialisasi perpajakan berpengaruh positif terhadap kesadaran wajib pajak orang pribadi. Nilai $p$ value variabel sosialisasi terhadap kepatuhan WP OP sebesar $<0,001$ lebih kecil dari 0,05 dan $\beta_{2}$ yang bernilai positif sebesar 0,286. Berdasarkan hasil tersebut $\mathrm{H}_{2}$ diterima yaitu sosialisasi perpajakan berpengaruh positif terhadap kepatuhan wajib pajak orang pribadi. Nilai signifikansi variabel kesadaran terhadap kepatuhan wajib pajak sebesar $<0,001$ lebih kecil dari 0,05 dan $\beta_{3}$ yang bernilai positif sebesar 0,548. Berdasarkan hasil tersebut $\mathrm{H}_{3}$ diterima yaitu kesadaran wajib pajak berpengaruh positif terhadap kepatuhan wajib pajak orang pribadi. Nilai signifikansi sosialisasi perpajakan sebesar $<0,001$ lebih kecil dari 0,05 dan variance indirect effect kesadaran wajib pajak memediasi pengaruh sosialisasi perpajakan terhadap kepatuhan wajib pajak sebesar $57,74 \%$. Hasil analisis yang dilakukan memberikan dukungan terhadap hipotesis keempat yang diajukan yaitu kesadaran wajib pajak memediasi pengaruh sosialisasi perpajakan terhadap kepatuhan wajib pajak orang pribadi $\left(\mathrm{H}_{4}\right.$ diterima). Variabel sosialisasi perpajakan dapat mempengaruhi kesadaran wajib pajak sebesar 50,4\% dan sisanya 49,6\% dijelaskan oleh faktor-faktor lain yang tidak dijelaskan dalam model jalur ini. Menurut penelitian 
terdahulu, variabel lain yang dimungkinkan dapat mempengaruhi kesadaran wajib pajak adalah motivasi wajib pajak, kualitas pelayanan, serta persepsi wajib pajak. Variabel sosialisasi perpajakan, dan kesadaran wajib pajak dapat mempengaruhi kepatuhan wajib pajak sebesar $58,5 \%$ dan sisanya $41,5 \%$ dijelaskan oleh faktor-faktor lain yang tidak dijelaskan dalam model jalur ini. Variabel lain yang dimungkinkan dapat mempengaruhi kepatuhan wajib pajak adalah persepsi wajib pajak, pembelajaran peraturan perpajakan, tarif pajak, motivasi wajib pajak, pemanfaatan teknologi informasi, sanksi perpajakan, serta kualitas pelayanan pajak

\section{DAFTAR PUSTAKA}

Basit, A. 2014. Pengaruh Persepsi Kontrol Perilaku, Pengetahuan Pajak Dan Persepsi Keadilan Pajak Terhadap Kepatuhan Wajib Pajak. Jurnal Tekun. V (01): 23- 48

Danarsi, Siti Nurlaela, dan Hendro Subroto. 2017. Faktor-Faktor Yang Mempengaruhi Kepatuhan Wajib Pajak Dalam Membayar Pajak Mobil Dengan Diberlakukannya Pajak Progresif Di Kota Surakarta. Jurnal Akuntansi Dan Pajak. 18 (01) :45-55

Direktorat Jenderal Pajak. 2013. Undang-Undang KUP Dan Peraturan Pelaksanaannya". Jakarta Selatan : Direktorat Penyuluhan, Pelayanan, dan Hubungan Masyarakat.

Faizin, M. R., Kertahadi, dan Ika Ruhana. 2016. Pengaruh Sosialisasi, Pemahaman, Dan Kesadaran Prosedur Perpajakan Terhadap Kepatuhan Wajib Pajak (Studi Pada Wajib Pajak Orang Pribadi Pajak Bumi Bangunan Perdesaan Dan Perkotaan Di Desa Mojoranu Kabupaten Bojonegoro). Jurnal Perpajakan (JEJAK). 9(1): 1-9

Ghozali, Imam.. 2016. Aplikasi Analisis Multivariate Dengan Program IBM SPSS 19. Semarang: Badan Penerbit Universitas Diponegoro

Ghozali, Imam dan Hengky Latan. 2014. Partial Least Squares Konsep, Metode, dan Aplikasi Menggunakan Program WarpPLS 4.0. Second Edition. Semarang : Badan Penerbit Universitas Diponegoro

Handoyono, R. 2014. Analisis Kepatuhan Wajib Pajak Orang Pribadi Di KPP Pratama Semarang Candisari. Akun-T. 2 (2) :215-240

Harinurdin, E. 2009. Perilaku Kepatuhan Wajib Pajak Badan. Bisnis \& Birokrasi. Jurnal Ilmu Administrasi dan Organisasi. 16 (2):96-104

Hasan, Iqbal. 2002. Pokok -Pokok Materi Metodologi Penelitian dan Aplikasinya. Jakarta : Ghalia Indonesia

Hidayat, W., dan Argo Adhi Nugroho. 2010. Studi Empiris Theory Of Planned Behavior Dan Pengaruh Kewajiban Moral Pada Perilaku Ketidakpatuhan Pajak Wajib Pajak Orang Pribadi. Jurnal Akuntansi Dan Keuangan. 12 (2):82-93

Kurniawan, H., Srikandi Kumadji, dan Fransisca Yaningwati. 2014. Pengaruh Sosialisasi Perpajakan Dan Persepsi Wajib Pajak Tentang Pelaksanaan Sensus Pajak Nasional Terhadap Kesadaran Wajib Pajak Orang Pribadi (Survei Terhadap Wajib Pajak Orang Pribadi Di Wilayah Banyuwangi). Jurnal Perpajakan. 3(1): 1-8

Manuputty, I.G., dan Swanto Sirait. 2016. Pengaruh Pengetahuan Perpajakan Dan Penerapan Self Assesment System Terhadap Kesadaran Wajib Pajak Serta Dampaknya Terhadap Kepatuhan Wajib Pajak Pada KPP Pratama Jakarta Panjaringan. 1(2) :44-58

Murtini, dan Alfi Hanafi. 2015. Pengaruh Pengetahuan Dan Pembelajaran Peraturan Perpajakan Terhadap Kepatuham Wajib Pajak Dengan Persepsi Sebagai Variabel Intervening (Studi Kasus Pada Umkm Di Kota Pekalongan). Jurnal Litbang.9: 88-99 
Murtopo, Purno, Sjafardamsah, dan Tugiman Binsarjono. 2011. PerpajakanPendekatan Sertifikasi A-B-C Edisi Pertama. Jakarta : Mitra Wacana Media

Pujangga, Raka F. 2017. Duh, Penerimaan Pajak di DJP I Jawa Tengah Baru 42 Persen" Direktorat Jenderal Pajak. 2016. Laporan Kinerja 2016". Diakses pada tanggal 14 November 2017. http://jateng.tribunnews.com/2017/08/11/duhpenerimaan-pajak-di-djp-i-jawa-tengah-baru-42-persen

Purba, B.P. 2016. Pengaruh Sosialisasi Perpajakan Dan Pemahaman Perpajakan Terhadap Kepatuhan Wajib Pajak Orang Pribadi Dengan Pelayanan Fiskus Sebagai Variabel Moderating Di Kantor Pelayanan Pajak Jakarta Kembangan. Media Akuntansi Perpajakan. 1 (2): 29-43

Puspita, Erna. 2016. Analisis Jalur Pengaruh Sosialisasi Terhadap Kepatuhan Wajib Pajak Bumi Dan Bangunan Kota Kediri Dengan Kesadaran Sebagai Variabel Intervening. Jurnal Akuntansi \& Ekonomi. 1 (1):1-8

Putra, R., Andri Suprayogi, dan Utomo Kahar. 2013. Aplikasi SIG Untuk Penentuan Daerah Quick Count Pemilihan Kepala Daerah (Studi Kasus : Pemilihan Walikota Cirebon 2013, Jawa Barat). Jurnal Geodesi Undip. 2 (4): 1-12

Setiyani, NM, Rita Andini, dan Abrar Oemar. 2018. Pengaruh Motivasi Wajib Pajak Dan Pengetahuan Perpajakan Terhadap Kepatuhan Wajib Pajak Orang Pribadi Dengan Kesadaran Wajib Pajak Sebagai Variabel Intervening (Pada Kantor Pelayanan Pajak Pratama Di Kota Semarang). Journal of Accounting. 1-18

Setyaningrum, T.A. 2017. Pengaruh Sosialisasi Dengan Mediasi Kesadaran Terhadap Kepatuhan Wajib Pajak Bumi Dan Bangunan Di Kota Pekalongan. Dokumen Karya Ilmiah Skripsi. Prodi Akuntansi - S1. Udinus. Feb 2017

Sudrajat, Ajat, dan Arles Parulian Ompusunggu. 2015. Pemanfaatan teknologi Informasi, Sosialisasi Pajak, Pengetahuan Perpajakan, dan Kepatuhan Pajak. Jurnal Riset Akuntansi dan Perpajakan .2 (2):193-202

Tiraada, T.A.M. 2013. Kesadaran Perpajakan, Sanksi Pajak, Sikap Fiskus Terhadap Kepatuhan Wpop Di Kabupaten Minahasa Selatan. Jurnal EMBA. 1(3) :9991008

Winerungan, O.L. 2013. Sosialisasi Perpajakan, Pelayanan Fiskus Dan Sanksi Perpajakan Terhadap Kepatuhan Wpop Di Kpp Manado Dan Kpp Bitung. Jurnal EMBA.1(3). September 2013: 960-970

Wulandari, Tuti. 2015. Pengaruh Sosialisasi Perpajakan, Pengetahuan Perpajakan, Dan Kualitas Pelayanan Terhadap Kepatuhan Wajib Pajak Dengan Kesadaran Wajib Pajak Sebagai Variabel Intervening (Studi Pada Kantor Pelayanan Pajak Pratama Pekanbaru Senapelan). Jom FEKON. 2 (2): 1-15 